\title{
In situ estimates of larval development and mortality in the New Zealand sea urchin Evechinus chloroticus (Echinodermata: Echinoidea)
}

\author{
Miles D. Lamare*, Michael F. Barker \\ Department of Marine Science, University of Otago, PO Box 56, Dunedin, New Zealand
}

\begin{abstract}
Synchronous spawning of the sea urchin Evechinus chloroticus Valenciennes in a closed fiord population (Doubtful Sound, New Zealand) provided a unique opportunity to calculate in situ rates of larval mortality and development. The resulting cohort of larvae was sampled $7 \mathrm{~d}$ after this spawning, and subsequently every 2 wk at 5 sites throughout the fiord. Instantaneous mortality rates for $E$. chloroticus larvae were calculated using 3 different models. Mortality $(M)$ was found to be constant and estimated at $M=0.164,0.173$, and $0.085 \mathrm{~d}^{-1}$ for the 3 models; the most accurate estimate of mortality probably being $M=0.164 \mathrm{~d}^{-1}$. Larvae reach competency in Doubtful Sound between 18 and $31 \mathrm{~d}$, which is 1.05 - to 1.82 -fold slower than maximum growth rates recorded in laboratory cultures. Larvae spent most of their development time $(44.9 \%)$ as 4 -armed plutei, and only a small proportion of these larvae $(11.5 \%)$ survived beyond this stage. We suggest that the slower in situ larval development rate and the accumulation of larvae in the 4 -armed pluteus stage indicate that these larvae are foodlimited in the plankton. Given the high daily mortality rate, these food-limited early pluteus larvae may be a critical life history stage for E. chloroticus populations in Doubtful Sound.
\end{abstract}

KEY WORDS: Echinoid - Larvae - Larval mortality - Larval nutrition - Larval development - Larval growth - Larval morphometrics Evechinus chloroticus

\section{INTRODUCTION}

Many marine species have a planktonic larval stage in their life history. Recruitment success of such species depends to a large extent on the survival of embryos and larvae, which is, in turn, governed by larval mortality and development time, which are related to each other by the equation

$$
N_{\mathrm{R}}=N_{0} \mathrm{e}^{-M d}
$$

where $N_{\mathrm{R}}$ : number of larvae surviving to settlement; $N_{0}$ : initial number of fertilised eggs; $M$ : instantaneous mortality rate; and $d$ : total development time.

Mortality in marine invertebrate larvae is considered to be high and largely due to predation (see reviews by

\footnotetext{
- Present address: Friday Harbor Laboratories, University of Washington, Friday Harbor, Washington 98250, USA.

E-mail: lamare@fhl.washington.edu
}

Young \& Chia 1987, Morgan 1995). There is, however, a paucity of quantitative estimates of mortality based on field data (Rumrill 1990). Typical estimates of the mortality rates commonly experienced by planktonic marine invertebrate larvae were reviewed by Rumrill (1990), where the average value for $M=0.247 \mathrm{~d}^{-1}$ Estimates of instantaneous mortality of echinoid larvae in the field are restricted to the Strongylocentrotus genus, and range from $M=0.063 \mathrm{~d}^{-1}$ to $M=0.266 \mathrm{~d}^{-1}$ (Rumrill 1987). Laboratory estimates of larval mortality cannot be extrapolated to the field; however, they do provide information on the susceptibility of echinoid larvae to predation (Rumrill 1990). Experiments on the predation of Dendraster excentricus (Rumrill et al. 1985, Pennington et al. 1986), S. purpuratus and S. franciscanus larvae (Rumrill \& Chia 1985) by zooplankton species indicate that the rate of predation is density dependent, and that the susceptibility of larvae to predation (and therefore larval mortality) is dependent on the 
stage of development. Rumrill \& Chia (1985) found predation rates by zoea larvae on 3 echinoid species were between 2 and 4 times higher for pre-pluteus stages than for pluteus stages. Pennington et al. (1986) documented a similar result for $D$. excentricus, but found vertebrate predation rates (fish species) were greater for pluteus stages than for the eggs and embryos.

Growth and development of echinoid larvae have been investigated in numerous laboratory experiments and in a smaller number of field studies (see reviews by Strathmann 1987, Boidron-Métairon 1995). Many of these laboratory studies have focused on the relationship between larval development and nutrition; from these studies 3 important conclusions can be drawn. Firstly, a positive correlation between development rate and food concentration commonly exists in laboratory-reared larvae. Secondly, food concentration influences the morphology of echinoid larvae, with relatively longer larval arms associated with lower food concentrations. This has been demonstrated in Paracentrotus lividus (Fenaux et al. 1988, 1994), Strongylocentrotus droebachiensis (Hart \& Scheibling 1988), Dendraster excentricus and Lytechinus variegatus (Boidron-Métairon 1988) and is almost certainly an adaptation to improve the feeding ability of the larvae by increasing the area of feeding cilia (McEdward 1984, 1985, 1986, Boidron-Métairon 1988, Hart \& Scheibling 1988). Thirdly, food quality influences the duration of larval development in echinoids. For $P$. lividus (Fenaux et al. 1988) food quality had a greater effect on 4-armed pluteus stages (which had few energy reserves to utilise) and on the rudiment stage than on the 6 - and 8-armed pluteus stages.

The degree to which the development of echinoid larvae, and especially rates of growth, is influenced by food availability within the plankton has been raised by several authors (Strathmann 1987, Fenaux et al. 1994). It is possible that nutrition has little importance to overall survival for several reasons: (1) echinoid larvae are generally insensitive to low concentrations of food (Olson \& Olson 1989) and are able to adapt through morphological plasticity (Hart \& Scheibling 1988) and the utilisation of lipid reserves (Fenaux et al. 1992); (2) larvae have been shown to grow at near maximum rates in food-poor water (Olson \& Olson 1989); and (3) concentrations of food in coastal waters are commonly sufficient for completion of larval development, and starvation of larvae in nature has never been documented. Despite these possibilities, foodlimited and sub-optimal growth has been demonstrated in the field for Paracentrotus lividus (Fenaux et al. 1994), and implied for Dendraster excentricus (Paulay et al. 1985) and the asteroid Acanthaster planci (Birkeland 1982).
Sub-optimal growth of echinoid larvae in the plankton is a significant phenomenon because it increases the time that larvae are exposed to predation and, hence, to high rates of mortality. Using Strongylocentrotus purpuratus as an example, with an $M$ in the plankton of $0.2658 \mathrm{~d}^{-1}$ (Rumrill 1987) and a total development time in the laboratory of between 29 and $86 \mathrm{~d}$ (Strathmann 1987), an increase in the total larval development time of $5 \mathrm{~d}$ would result in a $73 \%$ decrease in the number of larvae completing development.

This paper examines the growth and development of larvae of the sea urchin Evechinus chloroticus in a fiord, Doubtful Sound, on the south-west coast of New Zealand. E. chloroticus larvae are obligate planktivores that occur in the water column for approximately 1 mo during the austral summer (Lamare 1997). We repeatedly sampled a single cohort of E. chloroticus larvae within Doubtful Sound over a $7 \mathrm{wk}$ period between 3 February and 24 March 1994. This cohort almost certainly originated from a mass spawning of $E$. chloroticus populations observed in situ in Doubtful Sound on 27 January 1994 (Lamare \& Stewart 1998). In addition, previous studies on the distribution and transport of these larvae (Lamare 1998) indicated a high degree of larval retention occurred in Doubtful Sound over this $7 \mathrm{wk}$ period. Given these previous findings, in situ rates of development and mortality are calculated for $E$. chloroticus larvae. These results are discussed with reference to food-limited development of E. chloroticus larvae in Doubtful Sound.

\section{MATERIALS AND METHODS}

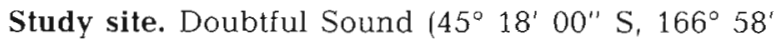
$\left.45^{\prime \prime} \mathrm{E}\right)$ is $-40 \mathrm{~km}$ long and on average $2 \mathrm{~km}$ wide (Fig, 1) and has depths within the fiord as great as $465 \mathrm{~m}$ (Fig. 1B). The average depth at the entrance of the fiord is shallower $(\sim 60 \mathrm{~m})$ due to the presence of sills and a number of islets. Doubtful Sound has a large input of fresh water that results in a distinct low salinity surface layer (LSSL) throughout the fiord, which can be up to $12 \mathrm{~m}$ thick and has typical salinities of 5 to $10 \%$. The seaward movement of this LSSL out of the fiord drives a compensatory flow of deeper seawater into the fiord, resulting in an estuarine circulation pattern, typical of the hydrography of many fiords (Pickard \& Emery 1982). The direction and speed of water flow within the deeper counter current can vary on a scale of days and is correlated with wind flux (Lamare 1998).

Plankton sampling. A mass spawning of Evechinus chloroticus was observed in Doubtful Sound on 27 January 1994 and resulted in a widely dispersed cohort of E. chloroticus larvae (Lamare \& Stewart 1998). Sam- 


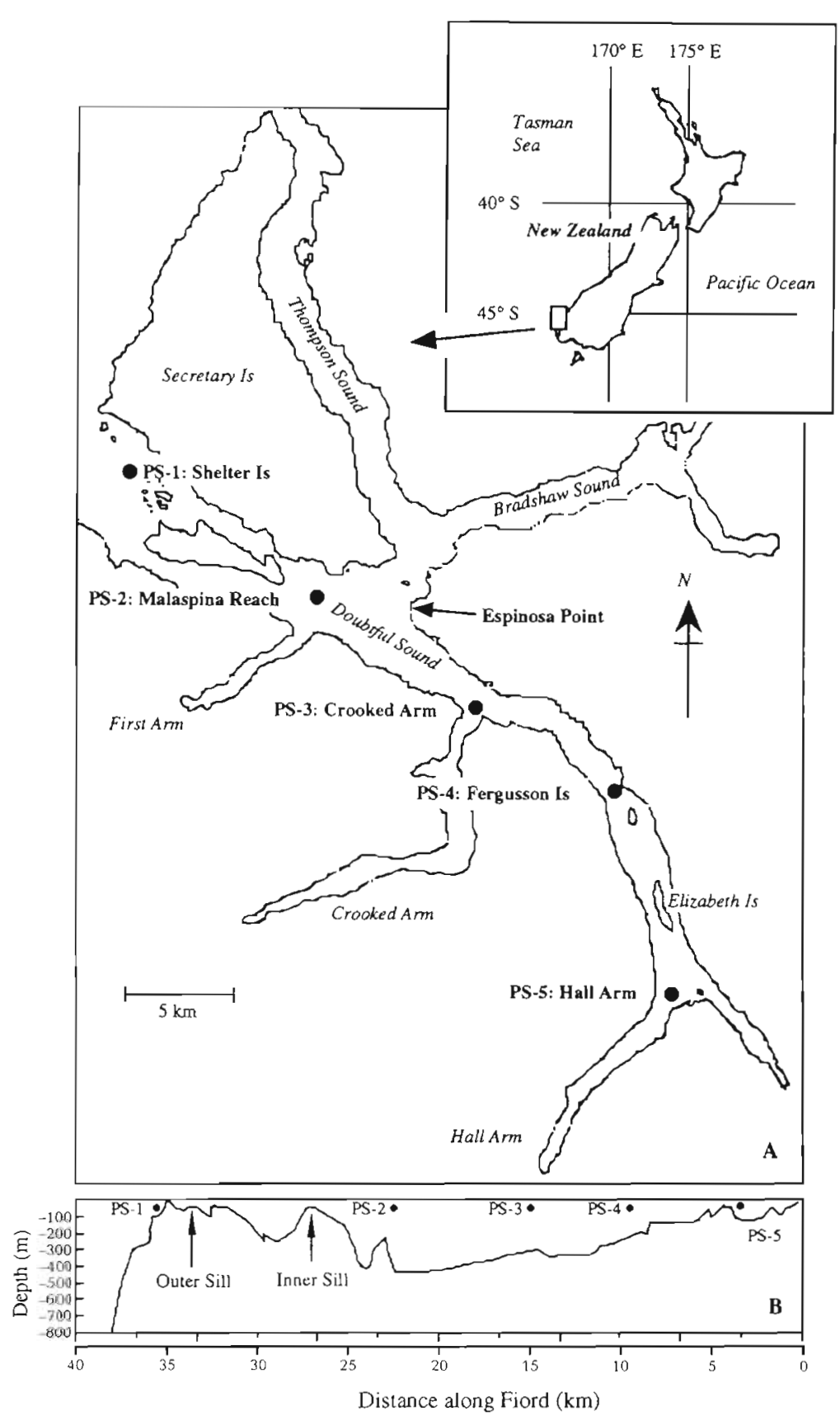

Fig. 1 (A) Location of the 5 plankton sampling sites (PS-1 to PS-5) within Doubtful Sound, New Zealand. (B) Cross section of the fiord showing the location of sites with respect to the 2 sills present. Espinosa Point, the site of fecundity and the adult and recruitment density estimates, is indicated

pling of these larvae was initiated $7 \mathrm{~d}$ after this spawning ( 3 February), and subsequently every 2 wk (14 and 27 February, 15 and 24 March) until no larvae were present in the plankton. On each date, replicate plankton samples were taken at 5 permanent stations located along a transect running from the head of Doubtful Sound to the entrance (Fig, 1). The sites were approximately equidistant, with 4 sites within the fiord (Sites PS-2 to PS-5), while 1 site (Site PS-1) was situated beyond the sill. Plankton samples were taken using a $100 \mu \mathrm{m}$ mesh UNESCO WP2 (UNESCO 1968) plankton net with a $50 \mathrm{~cm}$ diameter opening, hauled vertically for $100 \mathrm{~m}$ at a rate of $30 \mathrm{~cm} \mathrm{~s}^{-1}$. All samples were preserved immediately in $4 \%$ buffered formalin. Plankton samples were sorted and larvae counted within a Bogorov counting dish using a binocular microscope. The UNESCO WP2 plankton net has a mean catch efficiency of $94 \%$ in oligotrophic water (as in Doubtful Sound) for tows less than $16 \mathrm{~min}$ duration (Hernroth 1987). All tows in this study were less than 6 min duration and were assumed to have a catch efficiency of $100 \%$ that was constant over the course of the study. All larvae caught were classified into 1 of 10 developmental stages (Table 1, Fig. 2).

Larval development. The larval development rate was estimated from the temporal changes in the percentage-frequency distribution of larval stages at each site in Doubtful Sound, and from larvae reared in the laboratory. These lar-

Table 1. Evechinus chloroticus. Classification of larval developmental stages

\begin{tabular}{|ll|}
\hline Developmental stage & Notes \\
\hline Blastula & No larval arms present \\
Early 4-armed pluteus & Postoral and anterolateral arms present but neither at full length \\
4-armed pluteus & Both postoral and anterolateral arms fully formed. Gut obvious \\
Late 4-armed pluteus & 'Bud' postdorsal arms obvious \\
Early 6-armed pluteus & Postdorsal arms partially formed \\
6-armed pluteus & Postoral, anterolateral and postdorsal arms fully formed \\
Early 8-armed pluteus & Early development of preoral arms \\
8-armed pluteus & Postoral, anterolateral, postdorsal and preoral arms fully formed \\
8-armed pluteus with rudiment & Rudiment obvious but no sign of either tube feet or pedicellaria \\
Competent 8-armed pluteus & Tube feet and/or pedicellaria visible protruding from the larval body \\
\hline
\end{tabular}




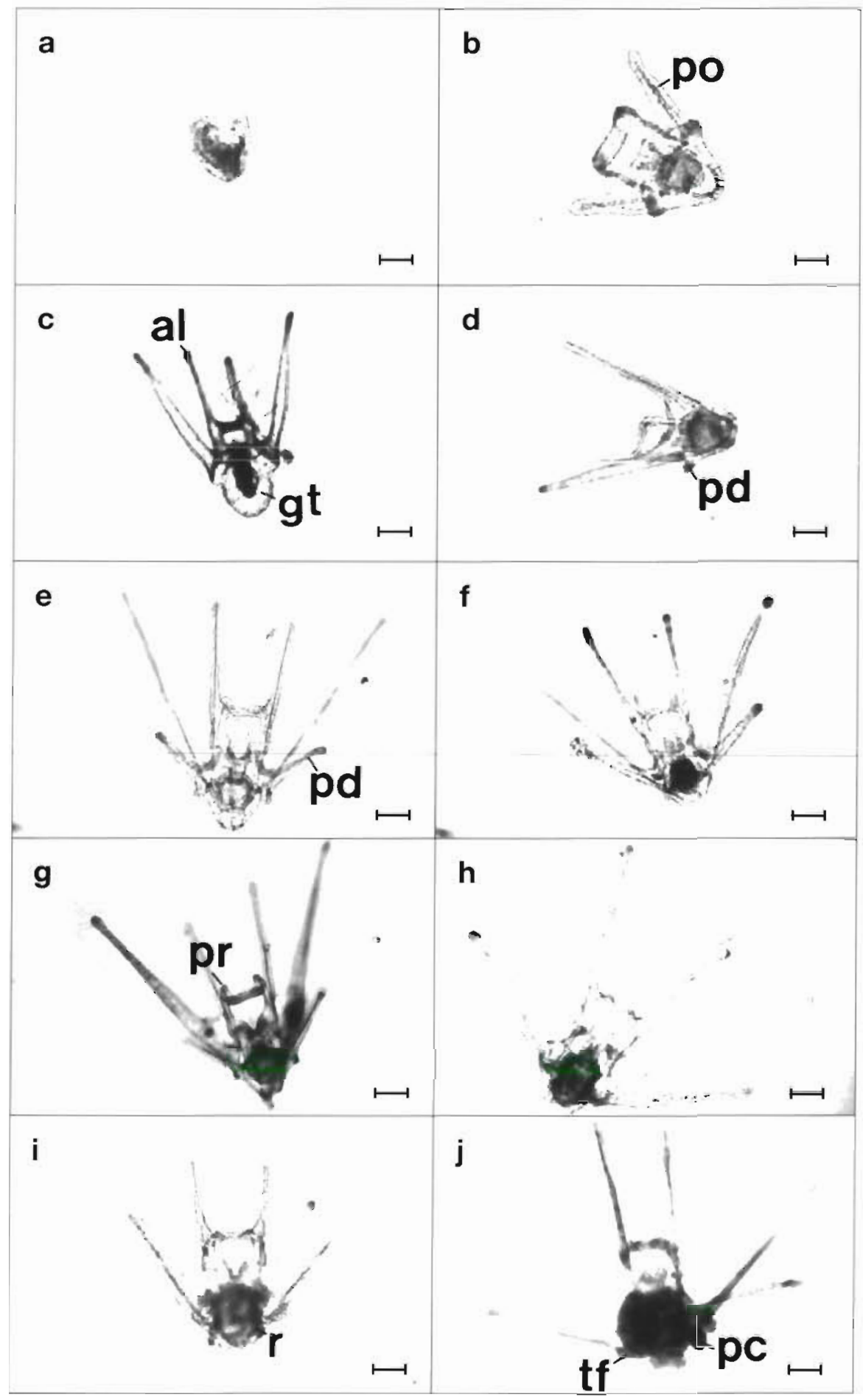

Fig. 2. Evechinus chloroticus. The 10 stages of larval development recognised in the current study: (a) blastula, (b) early 4 -armed pluteus, (c) 4-armed pluteus, (d) late 4-armed pluteus, (e) early 6-armed pluteus, (f) 6-armed pluteus, (g) early 8-armed pluteus, (h) 8-armed pluteus, (i) 8-armed pluteus with rudiment, (j) competent 8-armed pluteus. Larval structures identified are: al, antereolateral arm; gt, larval gut; pc, pedicellaria; $\mathrm{pd}$, postdorsal arm; po, postoral arm; pr, preoral arm; r, rudiment; tf, tube feet. See Table 1 for explanations. Scale bar $=200 \mu \mathrm{m}$ 
vae were cultured in $1000 \mathrm{l}$ tanks maintained at near ambient sea temperature $\left(14\right.$ to $18^{\circ} \mathrm{C}$ ), at densities of 1 larvae $\mathrm{ml}^{-1}$ and fed the alga Rhodomonas lens every $2 \mathrm{~d}$ at cell densities of 6000 cells $\mathrm{ml}^{-1}$.

Larval morphometrics. Morphometric measurements were made on randomly selected Evechinus chloroticus larvae during their development in the laboratory $(n=133$ ), and on larvae collected in Doubtful Sound on 3 February, 14 February and 27 February 1994. Measurements of larvae from the field were made on the first 20 larvae encountered at each site on each sampling date. For 27 February, no measurements were possible for the Shelter Islands site due to the small sample size $(\mathrm{n}=5)$. Two morphometric measurements were recorded for each larvae (Fig. 3). The first, the total length of the larva, was measured as the linear distance between the tip of the postoral arm and the ventral end of the larval body. The second, the length of the postoral arm, was measured as the linear distance between the tip of the postoral arm and the base of the postoral arm (that is, the junction of the postoral arm with the larval body). Both measurements were made using the computer program NIH Image Analyser (Rasband 1996), with the postoral skeletal rod used as a reference line for the linear measurements. All larvae examined underwent a degree of shrinkage due to preservation in $4 \%$ buffered formalin. The amount of shrinkage was not quantified but was assumed to be the same for each sample and for all parts of the larval body. For statistical analysis, the total larval length $(\mu \mathrm{m})$ and postoral arm length $(\mu \mathrm{m})$

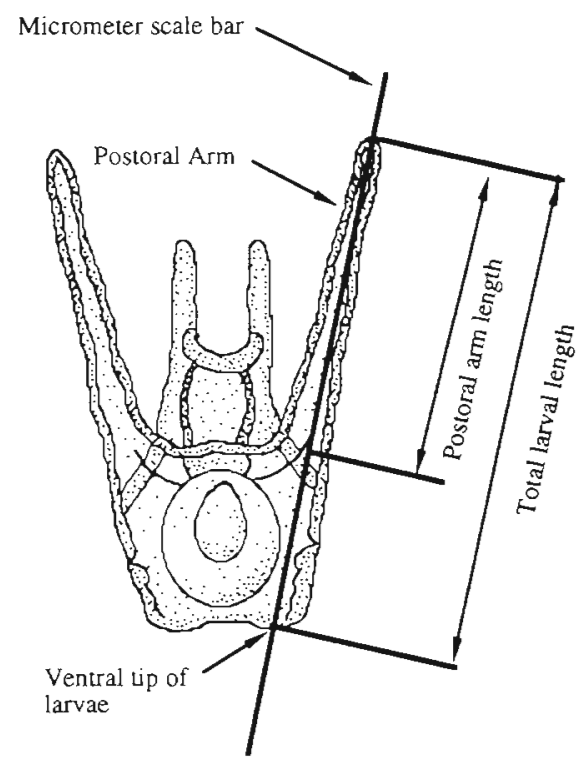

Fig. 3. Evechinus chloroticus. Two morphometric measurements on larvae using the 4 -armed pluteus larvae as an example: (1) the total larval length and (2) the length of the postoral arm measurements were $\ln (x)$ transformed and ANCOVA was used to test for differences in the relative size of the postoral arm length to the total larval length.

Larval mortality. Three models were used to calculate larval mortality of Evechinus chloroticus larvae in Doubtful Sound.

Model 1 (cohort analysis model): An average number of Evechinus chloroticus larvae tow ${ }^{-1}$ at each site was calculated for each sampling date and the instantaneous mortality rate $(M)$ of larvae between sampling periods was calculated using the equation

$$
M=\ln \left(N_{0} / N_{t}\right) /-t
$$

where $t=$ specific time interval; $N_{t}=$ number of larvae after a specific time interval $(t)$; and $N_{0}=$ initial number of larvae. Using this method, an $M$ was calculated for each of the 5 sites between each pair of the plankton sampling dates. An $M$ was also calculated for all 5 sites pooled and for the 4 inner fiord sites pooled over the sampling periods.

Model 2 (Kiritani-Nakasuji-Manly [KNM]): Manly (1976) expanded the Kiritani \& Nakasuji (1967) method of analysing stage-structured populations so that data on temporal changes in the frequency distribution of stages within a population can be used to estimate population parameters. If a population meets 3 conditions, (1) survival rate per unit time is the same in all stages over the sampling period, (2) sampling is started before any individuals have entered the first stage and continues until all individuals have died, and (3) immigration and emigration are negligible in the population, then the number of individuals in a stage at a given time is described by the equation

$$
f_{j}(t)=N_{j} \int_{t-a_{1}}^{t} g_{j}(x) \exp [-\theta(t-x)] \mathrm{d} x
$$

where $f_{j}(t)$ is the number of individuals in stage $j$ at time $t_{j} N_{j}$ is the number of individuals entering stage $j$; $g_{j}(x)$ is the probability density function for the time of entry into stage $j ; \exp (-\theta)$ is the survival parameter; and $a_{j}$ is the duration of stage $j$. Integration of this equation for $t$ between plus and minus infinity yields

$$
A_{j}=\int_{-\infty}^{+\infty} f_{j}(t) \mathrm{d} t=N_{i}\left[1-\exp \left(-\theta a_{j}\right)\right] / \theta
$$

which shows that the number under the stage-frequency curve $\left(A_{j}\right)$ is related to $\theta_{1}$ and $a_{j}$. If $f_{j}(t)$ is multiplied by $t$ before integration then

$$
D_{j}=\int_{-\infty}^{+\infty} t f_{j}(t) \mathrm{d} t=\left\{\mu_{j}+\frac{1}{\theta}-a_{j} \exp \left(-\theta a_{j}\right) /\left[1-\exp \left(-\theta a_{j}\right)\right]\right\} A_{j}
$$

which relates the area under the $t f_{j}(t)$ curve $D_{j}$ to the mean time of entry to the stage $\mu_{j}, \theta$, and $A_{j}$.

Because Eq. (3) was integrated over time, then Eqs. (4) \& (5) can be applied to the cumulated stagefrequencies of Evechinus chloroticus larvae from all sampling dates. It follows that, if $A_{j}^{*}$ and $D_{j}^{*}$ are the 
areas under the stage-frequency curves $F_{j}(t)$ and $t F_{j}(t)$ respectively for stages $j, j+1, \ldots, q$ combined, then

$$
A_{j}^{*}=N_{j} \theta
$$

and

$$
D_{j}^{*}=\left(\mu_{j}+\frac{1}{\theta}\right) A_{j}
$$

From Eqs. (6) \& (7) the stage-specific survival rate for stage $j$ is

$$
w_{l}=A_{j+1} / A_{j}^{*}=N_{j+1} / N_{j} \quad j=1,2, \ldots, q-1
$$

the survival parameter is

$$
\theta=-\log _{\epsilon}\left(A_{\dot{q}} / A_{j}^{j}\right) /\left(B_{q}^{*}-B_{i}^{*}\right)
$$

the instantaneous mortality rate is

$$
M=1-\exp (-\theta)
$$

the duration of stage $j$ is

$$
a_{j}=-\log _{\mathrm{e}}\left(w_{j}\right) / \theta \quad j=1,2, \ldots, q-1
$$

and the number entering stage $j$ is

$$
N_{j}=A_{j} \theta \quad j=1,2, \ldots, q-1
$$

where $B_{j}^{*}=D_{j}^{*} / A_{j}^{*}$

Analysis of the cumulative stage-frequency curves can be done using the trapezoidal rule, with area under the $F_{j}(t)$ curve for stage $f_{i j}$ at time $t$ estimated as

$$
\hat{A}_{j}^{*}=h \sum_{i=1}^{n} F_{i j}
$$

and the area under the $t F_{j}(t)$ curve estimated as

$$
\hat{D}_{j}^{*}=h \sum_{j=1}^{n} t_{1} F_{i j}
$$

Model 3 (production-recruitment): $M$ can be estimated from differences in larval production (fecundity) and subsequent post-settlement recruitment rates using the equation

given that

$$
\begin{gathered}
M=\ln (c / r) /-t \\
r=d_{\mathrm{r}} / d_{\mathrm{a}}
\end{gathered}
$$

where $c$ : fecundity $t$ : time between spawning and the measure of recruitment; $d_{r}$ : density of recruits; and $d_{\mathrm{a}}$ : density of adults.

Fecundity: c of Evechinus chloroticus females at Espinosa Point, Doubtful Sound (Fig. 1), was estimated for 8 individuals ranging in size from 70 to $90 \mathrm{~mm}$ test diameter. Samples were collected on 3 December 1993. prior to when $E$. chloroticus normally spawn in Doubtful Sound. Mean gonad indices of $20.4 \%(\mathrm{SE}=0.9$ ) were recorded for the population on this date, which are typical pre-spawning indices in the Espinosa Point population (Lamare 1997). For each female, spawning was induced by injecting a $0.5 \mathrm{M} \mathrm{KCl}$ solution through the peristomeal membrane into the coelom. One $\mathrm{ml}$ of $\mathrm{KCl}$ per $25 \mathrm{~g}$ wet weight of sea urchin was adminis- tered. The sea urchin was then inverted over a beaker containing $100 \mathrm{ml}$ of filtered seawater and allowed to spawn until it was apparent that no more eggs were being released. Following spawning, a $1 \mathrm{ml}$ subsample of well mixed egg/seawater suspension was removed and the number of eggs per $\mathrm{ml}$ suspension was calculated using a haemocytometer. The total number of eggs released was then calculated by multiplying the number of eggs per $\mathrm{ml}$ by the total volume of the seawater/egg suspension. The degree that $\mathrm{KCl}$ induced spawning over- or underestimates fecundity during natural spawning events in E. chloroticus was not quantified.

Recruitment: Mean adult density $\left(d_{a}\right)$ was calculated over a 3 yr period for the Evechinus chloroticus population at Espinosa Point (Fig. 1). Ten randomly placed transects were deployed perpendicular to the shore and 20 contiguous $1 \mathrm{~m}^{2}$ quadrats were sampled down each transect from MLWM (mean low water neap) to a depth of approximately $15 \mathrm{~m}$. All. E. chloroticus individuals occurring in the quadrats were counted. Density of recruits $\left(d_{r}\right)$ was estimated on 19 March 1993 ( 120 d after peak settlement was observed on artificial settlement surfaces at Espinosa Point) using an underwater airlift sampler. Eight randomly placed $1 \mathrm{~m}^{2}$ quadrats were sampled, 4 each at 6 and $10 \mathrm{~m}$ depths. These quadrats contained coralline algae encrusted rocks known to induce settlement in $E$. chloroticus (Walker 1984). The area within the quadrat was intensively sampled using the airlift, with collection efficiency improved by agitation of the substrate with a paint brush. Samples were retained in a $300 \mu \mathrm{m}$ mesh bag located at the top of the airlift, and later the number of $E$. chloroticus per $\mathrm{m}^{2}$ was counted using a dissecting microscope.

Sea temperatures and chlorophyll a concentrations. Chlorophyll a concentrations $\left(\mathrm{mg} \mathrm{m}^{-3}\right.$ ) were calculated at depths of 1 (within the low salinity layer), 10, 20,50 and $100 \mathrm{~m}$ at each of the sites on 14 December 1994 and 17 January, 9 February, 23 February, 7 March, 5 April and 27 April 1995. Two litre water samples were taken at each depth and the concentration of chlorophyll a determined spectrophotometrically using methods previously described (Strickland \& Parsons 1972). Sea temperatures in mid-Doubtful Sound at $10 \mathrm{~m}$ depth were monitored over the course of plankton sampling using Hobotemp ${ }^{\star}$ data loggers. Temperatures were recorded every $4 \mathrm{~h}$ to an accuracy of $0.1^{\circ} \mathrm{C}$.

\section{RESULTS}

\section{Larval development}

Evechinus chloroticus larvae were found in all samples taken between 3 February and 15 March 1994. 
Table 2. Evechinus chloroticus. Total number of larvae in each stage on each sampling date for each site. The total and mean $( \pm \mathrm{SE})$ number of larvae sampled on each date are given for each site. $\mathrm{A}$ : armed

\begin{tabular}{|c|c|c|c|c|c|c|c|c|c|c|c|c|c|c|c|}
\hline Date & Day & Blasstula & Early $4 \mathrm{~A}$ & $4 \mathrm{~A}$ & Late $4 \mathrm{~A}$ & \multicolumn{2}{|c|}{ Stage } & Early 8A & $8 \mathrm{~A}$ & 8A-rud & 8A-comp & Total & $\begin{array}{l}\text { No. of } \\
\text { tows }\end{array}$ & $\begin{array}{l}\text { Mean no } \\
\text { per tow }\end{array}$ & o. SE \\
\hline \multicolumn{16}{|c|}{ Shelter Islands } \\
\hline 3 Feb & 7 & 0 & 9 & 153 & 10 & 3 & 0 & 0 & 0 & 0 & 0 & 175 & 2 & 87.5 & 16.5 \\
\hline 14 Feb & 18 & 0 & 5 & 52 & 1165 & 3 & 0 & 0 & 1 & 1 & 0 & 1227 & 2 & 613.5 & 280.5 \\
\hline $27 \mathrm{Feb}$ & 31 & 0 & 0 & 0 & 1 & 1 & 1 & 0 & 0 & 2 & 1 & 6 & 3 & 2.0 & 0.6 \\
\hline $15 \mathrm{Mar}$ & 47 & 0 & 0 & 0 & 2 & 3 & 0 & 0 & 0 & 1 & 0 & 6 & 3 & 2.0 & 0.6 \\
\hline $24 \mathrm{Mar}$ & 56 & 0 & 0 & 0 & 0 & 0 & 0 & 0 & 0 & 0 & 0 & 0 & 3 & 0.0 & 0.0 \\
\hline \multicolumn{16}{|c|}{ Malaspina Reach } \\
\hline 3 Feb & 7 & 0 & 52 & 676 & 82 & 21 & 0 & 0 & 0 & 0 & 0 & 831 & 2 & 415.5 & 154.5 \\
\hline 14 Feb & 18 & 0 & 5 & 7 & 3401 & 8 & 18 & 0 & 19 & 6 & 0 & 3459 & 2 & 1729.5 & 379.5 \\
\hline $27 \mathrm{Feb}$ & 31 & 0 & 0 & 8 & 16 & 36 & 53 & 18 & 32 & 23 & 10 & 196 & 3 & 65.3 & 11.3 \\
\hline $15 \mathrm{Mar}$ & 47 & 0 & 0 & 1 & 16 & 3 & 0 & 0 & 1 & 1 & 1 & 23 & 3 & 8.5 & 1.5 \\
\hline 24 Mar & 56 & 0 & 0 & 0 & 0 & 0 & 0 & 0 & 0 & 0 & 0 & 0 & 3 & 0.0 & 0.0 \\
\hline \multicolumn{16}{|c|}{ Crooked Arm } \\
\hline 3 Feb & 7 & 0 & 7 & 116 & 8 & 1 & 0 & 0 & 0 & 0 & 0 & 132 & 2 & 66.0 & 15.0 \\
\hline $14 \mathrm{Feb}$ & 18 & 0 & 0 & 8 & 5461 & 3 & 4 & 0 & 10 & 0 & 0 & 5486 & 2 & 2743.0 & 568.9 \\
\hline 27 Feb & 31 & 0 & 0 & 1 & 10 & 15 & 74 & 22 & 67 & 66 & 60 & 315 & 3 & 105.0 & 19.5 \\
\hline $15 \mathrm{Mar}$ & 47 & 0 & 0 & 3 & 6 & 2 & 0 & 0 & 0 & 3 & 0 & 14 & 3 & 4.0 & 2.0 \\
\hline $24 \mathrm{Mar}$ & 56 & 0 & 0 & 0 & 0 & 0 & 0 & 0 & 0 & 0 & 0 & 0 & 3 & 0.0 & 0.0 \\
\hline \multicolumn{16}{|c|}{ Fergusson Island } \\
\hline 3 Feb & 7 & 0 & 20 & 664 & 28 & 8 & 0 & 0 & 0 & 0 & 0 & 720 & 2 & 360.0 & 205.0 \\
\hline 14 Feb & 18 & 0 & 4 & 42 & 3372 & 34 & 2 & 2 & 6 & 2 & 0 & 3464 & 2 & 1732.0 & 280.0 \\
\hline 27 Feb & 31 & 0 & 0 & 10 & 22 & 47 & 106 & 69 & 78 & 85 & 23 & 440 & 3 & 146.7 & 8.5 \\
\hline $15 \mathrm{Mar}$ & 47 & 0 & 0 & 11 & 2 & 2 & 0 & 0 & 1 & 2 & 0 & 18 & 3 & 6.0 & 2.0 \\
\hline $24 \mathrm{Mar}$ & 56 & 0 & 0 & 0 & 0 & 0 & 0 & 0 & 0 & 0 & 0 & 0 & 3 & 0.0 & 0.0 \\
\hline \multicolumn{16}{|c|}{ Hall Arm } \\
\hline $3 \mathrm{Feb}$ & 7 & 0 & 3 & 33 & 0 & 0 & 0 & 0 & 0 & 0 & 0 & 36 & 2 & 18.0 & 2.0 \\
\hline $14 \mathrm{Feb}$ & 18 & 0 & 0 & 6 & 716 & 2 & 1 & 0 & 5 & 0 & 2 & 732 & 2 & 366.0 & 51.0 \\
\hline $27 \mathrm{Feb}$ & 31 & 0 & 0 & 4 & 45 & 65 & 330 & 119 & 417 & 303 & 101 & 1383 & 3 & 461.0 & 165.9 \\
\hline $15 \mathrm{Mar}$ & 47 & 0 & 0 & 0 & 1 & 0 & 0 & 0 & 0 & 0 & 0 & 1 & 3 & 0.3 & 0.3 \\
\hline $24 \mathrm{Mar}$ & 56 & 0 & 0 & 0 & 0 & 0 & 0 & 0 & 0 & 0 & 0 & 0 & 3 & 0.0 & 0.0 \\
\hline
\end{tabular}

but were absent in samples taken on 24 March 1994 (Table 2). The percentage frequency distributions of larvae in each developmental stage between 3 February and 15 March 1994 are illustrated for each site in Fig. 4. On 3 February ( $7 \mathrm{~d}$ post-spawning) larvae ranged in development stage from early 4 -armed to early 6-armed, with the majority of larvae (86.7\%) having developed through to the 4 -armed stage. By 14 February (18 d post-spawning), almost all larvae sampled $(98 \%)$ had developed through to the late 4 -armed stage. A small number of more advanced larvae $(<0.5 \%)$ were present in the samples, including 2 competent larvae. Samples taken on 27 February (31 d post-spawning) contained larvae ranging from early 4-armed through to competent larvae. Larvae were distributed more evenly throughout the developmental classes, with the greatest percentage of larvae $(25.4 \%)$ occurring in the 8 -armed stage. Competent larvae made up $8.3 \%$ of the larvae sampled. Samples taken on 15 March contained only small numbers of $E$. chloroticus larvae ( $n=1$ to 23 ), mainly in the 4 -armed stage $(41.9 \%)$. No E. chloroticus larvae were present in samples taken on 24 March.

The similar spatial distributions of developmental stages within Doubtful Sound suggest that development rates of Evechinus chloroticus larvae varied little throughout the fiord. The frequency distribution of developmental stages was almost identical at each site on 3 February and 14 February. On 27 February, the 4 inner fiord sites had comparable distributions, with most of the larvae in the 6-armed larvae (23.4 to $27.0 \%$ ). Advanced larval stages were present at all sites, with the percentage of competent larvae ranging from 5.1 to $19.1 \%$. Assuming a single, synchronous spawning occurred in 1994, the development rates of individual larvae were initially very similar, but became variable over time. On 14 February for example, $98.0 \%$ of larvae sampled were of similar development. By 27 February larvae were distributed throughout a range of developmental classes, indicating a higher degree of individual variation in the rate of development among larvae. The distribution of developmental 


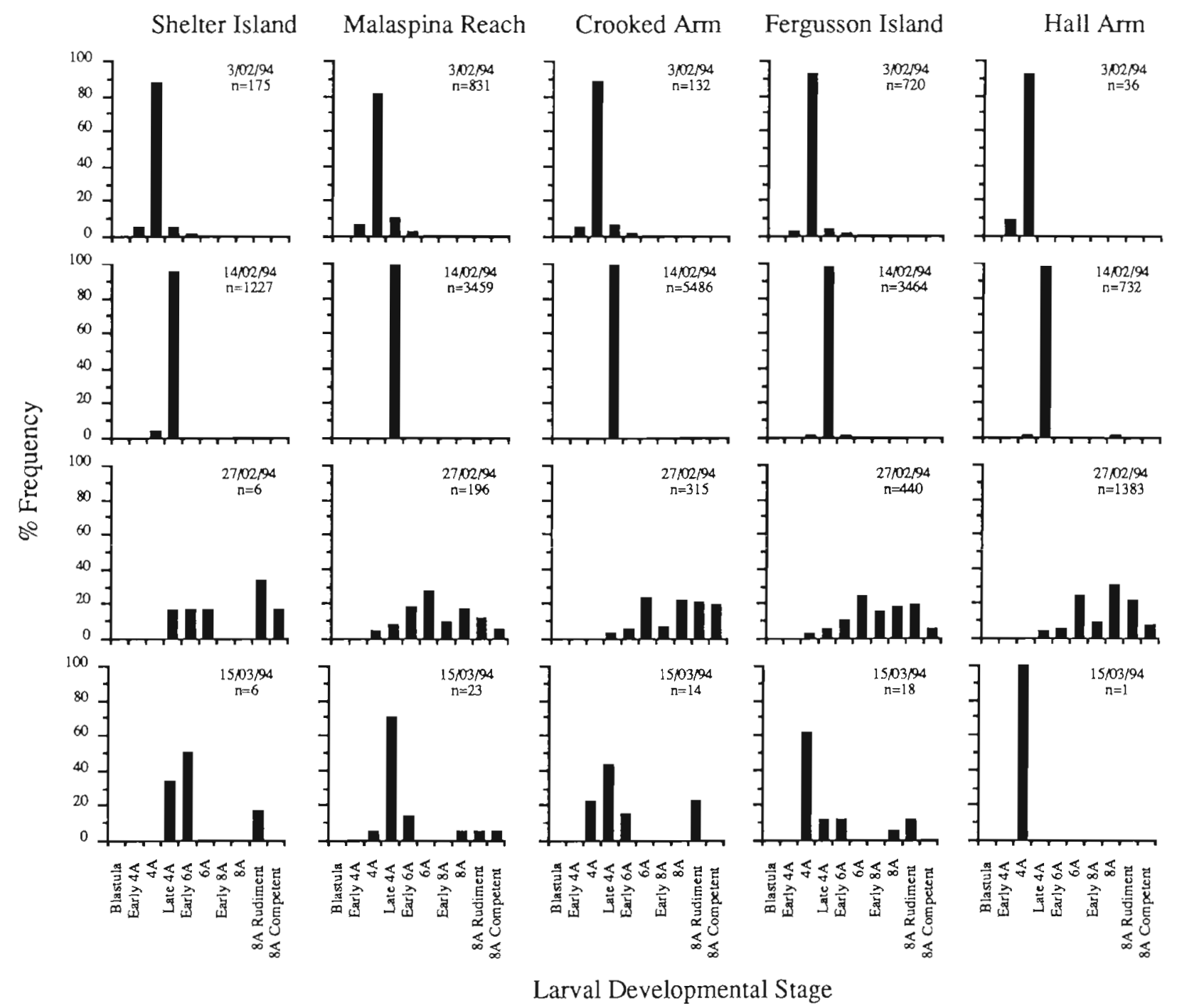

Fig. 4. Evechinus chloroticus. Percentage frequency distribution of larvae in each developmental stage within Doubtful Sound between 3 February and 15 March 1994 at each sample site (A: armed). n: number of larvae sampled on each sampling date (given as $\mathrm{d} / \mathrm{mo} / \mathrm{yr}$ )

stages indicates that larvae reach competency some time between 18 and $31 \mathrm{~d}$. Development rates of $E$. chloroticus larvae in the laboratory are shown in Table 3 ; the mean time to reach competency for these larvae was between 22 and $23 \mathrm{~d}$.

\section{Larval morphometrics}

The allometric relationship between total larval length and larval arm length differed significantly between field and laboratory larvae (Fig. 5). ANCOVA of $\ln$ (total larval length) versus $\ln$ (postoral arm length) between field and laboratory larvae showed that the slopes were heterogeneous $(p<0.001$,
Table 4). Larvae from the field had significantly longer arms compared to cultured larvae of the same total length. On average, the arm length was $55.1 \%$ ( $\mathrm{SE}=$ 0.49 ) of the total length of the larvae in the Iaboratory, and $64.6 \%$ (SE $=0.61)$ of the total length in. Doubtful Sound.

\section{Larval mortality}

Model 1 (cohort analysis)

The average number of Evechinus chloroticus larvae per tow at each site within Doubtful Sound initially increased from the first to the second sampling date 
(Fig 6). Larval densities for all sites were highest in 14 February samples, averaging 1437.3 larvae tow $^{-1}$ for all sites (Table 2). An order of magnitude decrease occurred over the following 2 wk period, resulting in an average larval density on 27 February of 156.0 larvae tow ${ }^{-1}$ for all sites. Between 27 February and 15 March larval densities decreased further to an average of 4.1 larvae tow ${ }^{-1}$ throughout the fiord.

Assuming that larval transport out of the fiord and metamorphosis rates were negligible in Doubtful Sound, and that mortality rates were the same for all larval stages, the $M\left(\mathrm{~d}^{-1}\right)$ for each site was calculated directly from changes in larval densities between 14 February and 24 March (Table 5). $M$ averaged $0.171 \mathrm{~d}^{-1}$ between 14 and 27 February for all 5 sites pooled, and $M=0.164 \mathrm{~d}^{-1}$ for the 4 inner fiord sites pooled. $M$ was 0.242 and $0.248 \mathrm{~d}^{-1}$ respectively for these groups of sites for the period between 27 February and 15 March. $M$ from 14 February and 15 March was calculated at $0.209 \mathrm{~d}^{-1}$ for all sites pooled and for the 4 inner sites pooled.

\section{Model 2 (Kiritani-Nakasuji-Manly)}

To check the assumption of a constant mortality rate of Evechinus chloroticus larvae, the logarithms of the

Table 3. Evechinus chloroticus. Time for development to 5 successive larval stages of larvae reared in the laboratory at a density of 1 larva $\mathrm{ml}^{-1}$, and fed the algae Rhodomonas lens $\left(6000\right.$ cells $\left.\mathrm{ml}^{-1}\right)$. The range and mean water temperatures $\left({ }^{\circ} \mathrm{C}\right)$ of each culture are given

\begin{tabular}{|c|c|c|c|c|}
\hline & \multicolumn{3}{|c|}{ Days to reach developmental stage } & \multirow[t]{2}{*}{ Mear } \\
\hline & Culture 1 & Culture 2 & Culture 3 & \\
\hline Fertilization & 2 Dec 1997 & 2 Mar 1998 & $22 \operatorname{Dec} 1997$ & - \\
\hline Blastula & 2 & 2 & 2 & 2 \\
\hline 4-armed & 6 & 4 & 5 & 5 \\
\hline 6 -armed & _- & 8 & 9 & 8.5 \\
\hline 8 -armed & 14 & 14 & 14 & 14 \\
\hline Competent larvae & 22 & 23 & - & 22.5 \\
\hline Temperature range & $13.5-16.5$ & $14.5-18.1$ & $14-16.5$ & \\
\hline Mean temperature & 14.6 & 16.2 & 15.3 & 15.4 \\
\hline
\end{tabular}

Table 4. ANCOVA of In(total larval length) versus $\ln$ (postoral arm length) for Evechinus chloroticus larvae from Doubtful Sound $(\mathrm{n}=280)$ and reared in the laboratory $(n=133)$. The dependent variable is $\ln$ (postoral arm length) and the covariant is $\ln$ (total larval length)

\begin{tabular}{|lrrrrrr|}
\hline $\begin{array}{l}\text { Homogeneity of slopes } \\
\text { ANCOVA }\end{array}$ & SS & df & MS & F-ratio & $p$ \\
\hline Total larval length & 35.886 & 1 & 35.886 & 4112.842 & $<0.000$ \\
Location (lab/field) & 0.241 & 1 & 0.241 & 27.651 & $<0.000$ \\
Location $\times$ Total larval length & 0.290 & 1 & 0.290 & 33.234 & $<0.000$ \\
Error & 3.569 & 409 & 0.009 & & \\
\hline
\end{tabular}

total number of larvae sampled on each date were plotted against time (Fig. 7). The linear decrease in the descending limb of the plot indicates a constant $M$ of $0.231 \mathrm{~d}^{-1}$.

Table 6A shows the number of Evechinus chloroticus larvae in each stage on each sampling date for all sites pooled. Though not measured, the density of larvae immediately prior to spawning on 27 January was assumed to be zero. From these data, cumulated stage-frequencies were calculated for each sampling date (Table 6B), and $\hat{A}_{j}^{*}$ and $\hat{D}_{j}^{*}$ were calculated for each stage using Eqs. (13) \& (14) respectively (Table 7). Eqs. (8), (10), (11) \& (12) were applied to these data to calculate the stage-specific survival rates, the instantaneous mortality rate, proportion of time spent in each stage, and the number of larvae entering each stage respectively (Table 8 ).

The KNM model estimated an $M$ of $0.173 \mathrm{~d}^{-1}$ for Evechinus chloroticus larvae. The proportion of time larvae spent in each stage was not equal, with larvae spending the longest time in the 


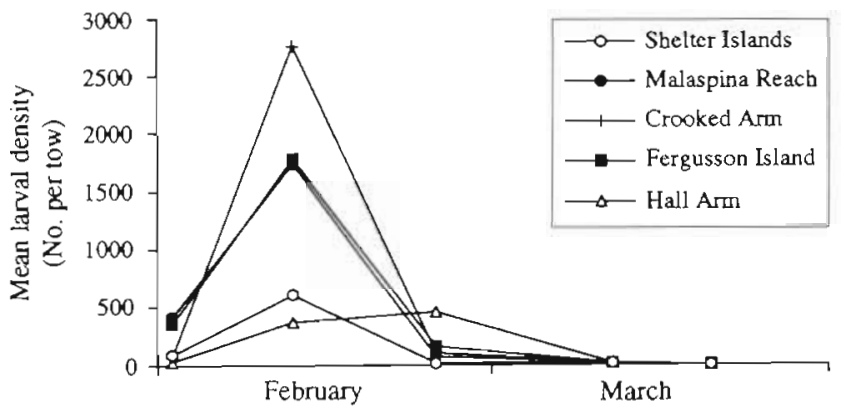

Fig. 6. Evechinus chloroticus. Temporal changes in the mean density of larvae at 5 sites within Doubtful Sound between 3 February and 24 March 1994

late 4 -armed (44.9\%) and 8-armed with rudiment stages $(26.1 \%)$. A consequence of the constant mortality rate is that the stage-specific survival rate is a function of the time spent in each stage. For this reason only $11.5 \%$ of larvae survived through the late 4 armed stage and only $28.5 \%$ survived the 8 -armed with rudiment stage, while survival was higher through the shorter-lived stages. The estimates of the numbers of larvae entering each stage suggest that only $0.7 \%$ of early 4 -armed larvae survive through to the 8 -armed with rudiment stage.

\section{Model 3 (production-recruitment)}

Fecundity (c) in Evechinus chloroticus was estimated at $1.2 \times 10^{6}\left(\mathrm{SE}=0.13 \times 10^{6}\right)$, and development time of larvae in Doubtful Sound is between 18 and $31 \mathrm{~d}$. The mean density of adult $E$. chloroticus at Espinosa point was $1.30 \mathrm{~m}^{-2}$ over the 3 years of sampling, and density of recruits ( $120 \mathrm{~d}$ post-settlement) at the same site was found to be $2.38 \mathrm{~m}^{-2}$. Given $t=138$ to $151 \mathrm{~d}$ (18 to $31 \mathrm{lar}$ val development days +120 post-settlement days) then

Table 5. Evechinus chloroticus. Estimated instantaneous mortality rates of larvae $\left(\mathrm{d}^{-1}\right)$ at 5 sites in Doubtful Sound at $2 \mathrm{wk}$ intervals, and for the $30 \mathrm{~d}$ period between 14 February and 15 March 1994. Instantaneous mortality rates are also calculated for the mean larval densities of all 5 sites pooled, and for the mean larval densities of the 4 inner fiord sites pooled

\begin{tabular}{lcccc|}
\hline & 14 Feb-27 Feb & 27 Feb-15 Mar & 14 Feb-15 Mar & 15 Mar-24 Mar \\
\hline Shelter Islands & 0.441 & $\mathrm{~d}$ & 0.205 & 1.000 \\
Malaspina Reach & 0.253 & 0.134 & 0.190 & 1.000 \\
Crooked Arm & 0.251 & 0.218 & 0.233 & 1.000 \\
Fergusson Island & 0.190 & 0.213 & 0.202 & 1.000 \\
Hall Arm & $\mathrm{d}$ & 0.489 & 0.254 & 1.000 \\
All sites pooled & 0.171 & 0.242 & 0.209 & 1.000 \\
Inner 4 sites pooled & 0.164 & 0.248 & 0.209 & 1.000 \\
atarval densities had increased over the 2 wk period & \\
\hline
\end{tabular}

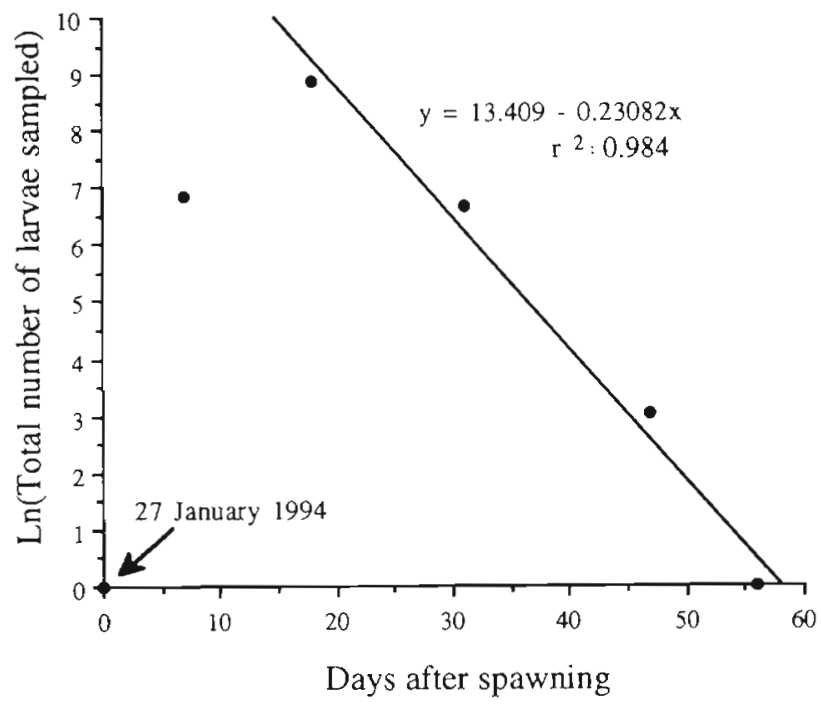

Fig. 7. Evechinus chloroticus. Lincar regression of $\ln$ (total number of larvae tow $w^{-1}$ in each larval stage) versus time since spawning for larvae sampled in Doubtful Sound between 3 February and 24 March 1994

$M=\left\{\ln \left[1.2 \times 10^{6} /\left(2.38 \mathrm{~m}^{-2} / 2.50 \mathrm{~m}^{-2}\right)\right]\right\} / t$ days

This yields an Mranging from 0.088 to $0.097 \mathrm{~d}^{-1}$ (mean $=0.092 \mathrm{~d}^{-1}$ ) depending on larval development time.

\section{Sea temperature and chlorophyll a concentrations}

During the time that Evechinus chloroticus larvae were present in Doubtful Sound, sea temperatures in the mid-region of the fiord ranged from 12.5 to $17.2^{\circ} \mathrm{C}$, peaking on 5 March (Fig. 8). Mean sea temperature over this period was $15.03^{\circ} \mathrm{C}$. Mean chlorophyll a concentrations in Doubtful Sound between 14 December 1994 and 27 April 1995 ranged from 0.123 to $1.940 \mathrm{mg}$ $\mathrm{m}^{-3}$ (Table 9). Concentrations were highest on 14 December, decreased with time, and tended to be lowest in the mid-regions of the fiord.

\section{DISCUSSION}

A widespread cohort of Evechinus chloroticus larvae originated from a mass spawning within Doubtful Sound on 27 January 1994, a proportion of which was retained within Doubtful Sound over the following $56 \mathrm{~d}$ period and subsequently completed development within the fiord. Seven days after spawning $86.7 \%$ of 
Table 6. Evechinus chloroticus. (A) Sum for all sites pooled of the mean number of larvae per tow in each developmental stage on each sampling date. (B) Corresponding cumulative stage-frequency distributions for each date

\begin{tabular}{|c|c|c|c|c|c|c|c|c|c|c|c|}
\hline \multirow[t]{2}{*}{ Date } & \multirow[t]{2}{*}{ Day } & \multicolumn{9}{|c|}{ Stage } & \multirow[t]{2}{*}{ Total } \\
\hline & & Early $4 \mathrm{~A}$ & $4 \mathrm{~A}$ & Late $4 \mathrm{~A}$ & Early $6 \mathrm{~A}$ & $6 \mathrm{~A}$ & Early $8 \mathrm{~A}$ & $8 \mathrm{~A}$ & 8A-rud & $8 \mathrm{~A}-\mathrm{comp}$ & \\
\hline \multicolumn{12}{|c|}{ (A) Sum of the mean number of larvae per stage (all sites pooled) } \\
\hline $27 \mathrm{Jan}$ & 0 & 0 & 0 & 0 & 0 & 0 & 0 & 0 & 0 & 0 & 0.0 \\
\hline 3 Feb & 7 & 45.5 & 821 & 64 & 16.5 & 0 & 0 & 0 & 0 & 0 & 947.0 \\
\hline 14 Feb & 18 & 7 & 57.5 & 7057.5 & 25 & 12.5 & 1 & 20.5 & 4.5 & 1 & 7186.5 \\
\hline 27 Feb & 31 & 0 & 7.7 & 31.3 & 54.7 & 188 & 76 & 198 & 159.8 & 65 & 780.5 \\
\hline $15 \mathrm{Mar}$ & 47 & 0 & 5 & 8.7 & 3.3 & 0 & 0 & 0.7 & 2.3 & 0.3 & 20.3 \\
\hline $24 \mathrm{Mar}$ & 56 & 0 & 0 & 0 & 0 & 0 & 0 & 0 & 0 & 0 & 0.0 \\
\hline \multicolumn{12}{|c|}{ (B) Cumulative stage frequencies (all sites pooled) } \\
\hline $27 \mathrm{Jan}$ & 0 & 0 & 0 & 0 & 0 & 0 & 0 & 0 & 0 & 0 & \\
\hline 3 Feb & 7 & 947 & 901.5 & 80.5 & 16.5 & 0 & 0 & 0 & 0 & 0 & \\
\hline $14 \mathrm{Feb}$ & 18 & 7186.5 & 7179.5 & 7122 & 64.5 & 39.5 & 27 & 26 & 5.5 & 1 & \\
\hline $27 \mathrm{Feb}$ & 31 & 780.5 & 780.5 & 772.8 & 741.5 & 686.8 & 498.8 & 422.8 & 224.8 & 65 & \\
\hline $15 \mathrm{Mar}$ & 47 & 20.3 & 20.3 & 15.3 & 6.6 & 3.3 & 3.3 & 3.3 & 2.6 & 0.3 & \\
\hline 24 Mar & 56 & 0 & 0 & 0 & 0 & 0 & 0 & 0 & 0 & 0 & \\
\hline
\end{tabular}

Table 7 Evechinus chloroticus. Estimates of $\hat{A}_{j}$ and $\hat{D}_{j}^{*}$, using the trapezoid rule, of the areas under the cumulative stage-frequency curves $F_{j}(t)$ and $t F_{j}(t)$ respectively for each larval stage over the integrated sampling dates. $\hat{B}_{j}^{;}$is calculated $\hat{D}_{i}^{*} / \hat{A}_{i}$

\begin{tabular}{|lrrc|}
\hline \multicolumn{1}{|c}{$j$} & \multicolumn{1}{c}{$\hat{A}_{j}^{*}$} & \multicolumn{1}{c|}{$\hat{D}_{j}^{*}$} & $\hat{B}_{j}^{*}$ \\
\hline Early 4-armed & 100064.2 & 2225644.3 & 22.24 \\
4-armed & 99476.2 & 2218180.6 & 22.30 \\
Late 4-armed & 89494.7 & 2095362.3 & 23.41 \\
Early 6-armed & 9285.9 & 300604.4 & 32.37 \\
6-armed & 8171.5 & 270022.1 & 33.04 \\
Early 8-armed & 5925.9 & 196137.9 & 33.10 \\
8-armed & 5063.5 & 167286.8 & 33.04 \\
8-armed with rudiment & 2608.5 & 87281.2 & 33.46 \\
Competent 8-armed & 742.6 & 24862.2 & 33.48 \\
\hline
\end{tabular}

larvae had developed through to the 4-armed pluteus stage, and after $18 \mathrm{~d} 98.0 \%$ had developed to the late 4 -armed pluteus stage. One month after spawning, 25.4 and $20.5 \%$ of larvae had developed through to the 8-armed and 8-armed with rudiment stages respectively, and a total of $8.3 \%$ of larvae were found to be competent. Almost no competent $E$. chloroticus larvae were found in plankton samples taken on 3 and 14 February (18 d post-spawning), but were present in 27 February plankton samples (31 d post-spawning). By 15 March (47 d post-spawning), very few larvae were found in the plankton samples $(0.33 \%$ of the total number of larvae sampled). These findings indicate that almost all larvae reach competency after $18 \mathrm{~d}$, and that all larvae had died, settled or been flushed out of the fiord by $56 \mathrm{~d}$ post-spawning.

Accurately estimating mortality of Evechinus chloroticus larvae in the plankton requires choosing the most appropriate model. In this study, mortality was assumed to be constant over time and not stage-specific. This assumption was tested by a linear regression of the logarithm of total numbers of larvae sampled on each date against time. The results indicated a constant mortality rate existed between the 4 -armed and competent larval stages of $M=0.23 \mathrm{~d}^{-1}$. While indicating that mortality was constant, it probably overestimates mortality because it incorporates decreases in numbers of larvae due to the settlement of competent larvae. 


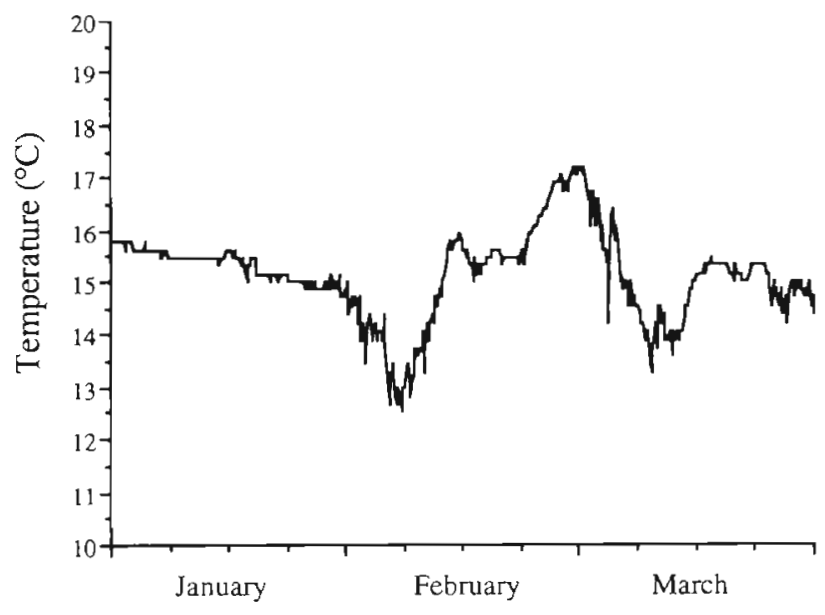

Fig. 8. Sea temperature $(10 \mathrm{~m}$ depth) within Doubtful Sound between 1 January and 30 March 1994

Three other estimates of mortality were made, the first from changes in larval densities between each sampling period (cohort analysis). This method assumes that all larvae in Doubtful Sound had originated from a single spawning event on 27 January 1994, and that no larvae immigrated to or emigrated from Doubtful Sound. Given these assumptions, highest larval densities would be expected to occur in the first plankton samples taken after spawning. This was not found during plankton sampling, with larval densities lower in the first samples ( 3 February, mean = 189.4 larvae tow ${ }^{-1}$ ) than in the following samples (14 February, mean $=1437.3$ larvae tow ${ }^{-1}$ ). An increase in larval densities would result from an advection of Evechinus chloroticus larvae into the fiord, or from a spawning event between 3 and 14 February (although the distribution of larval development stages suggests only 1 cohort of larvae was present during this period). An alternative explanation is that the plankton samples were taken mid-fiord at each site (which is on average $1 \mathrm{~km}$ from the $E$. chloroticus populations that occur peripherally in the fiord), and the $7 \mathrm{~d}$ post- spawning period prior to the first plankton samples may not have been sufficient time for larvae to be advected to the centre of the fiord and be sampled. Given the latter explanation, the most accurate estimate of $M$ using this model is probably $0.164 \mathrm{~d}^{-1}$. This was calculated for the 4 inner fiord sites which undergo low rates of larval advection (Lamare 1998) and between 14 and 27 February when settlement rates were probably negligible. The second model of mortality in E. chloroticus larvae, the KNM model, estimated $M$ at $0.173 \mathrm{~d}^{-1}$, which was constant for all larval stages.

The last model applied, the production-recruitment model estimated $M$ at $0.092 \mathrm{~d}^{-1}$. This model inherently underestimates larval mortality because it incorporates the mortality of post-settlement stages, which is almost certainly lower than in the larval stages. An accurate estimate of larval mortality using this model requires information on settlement densities of Evechinus chloroticus. No quantitative estimates exist for $E$. chloroticus; however, densities of newly settled sea urchins are typically high. Rowley (1990) reported densities for Strongylocentrotus purpuratus of $\sim 20$ per $200 \mathrm{~cm}^{2}\left(-1000 \mathrm{~m}^{-2}\right)$ and Harris (1995) found settling densities of $S$. droebachiensis of between 7372.5 and $30237.8 \mathrm{~m}^{-2}$. Given a similar range of settlement densities for $E$. chloroticus in Doubtful Sound, a mean adult density of $1.3 \mathrm{~m}^{-2}$, the larval life span of $31 \mathrm{~d}$ and fecundity rate of $1.2 \times 10^{6}$ eggs ind. 1 , Model 3 would yield an average $M=0.178 \mathrm{~d}^{-1}\left(0.127\right.$ to $\left.0.237 \mathrm{~d}^{-1}\right)$.

These modelling exercises suggest that mortality of Evechinus chloroticus larvae is constant and in the range of $M=0.16$ to $0.18 \mathrm{~d}^{-1}$. Previous estimates of invertebrate larval mortality (Table 10) include 28 estimates of $M$ using changes in the density of larvae within a cohort, which average $M=0.247 \mathrm{~d}^{-1}$, and 14 estimates using the production-recruitment model, which average $M=0.147 \mathrm{~d}^{-1}$. In an alternative method, $M$ in echinoid larvae has been estimated from the ratio needed to balance differences in fecundity, egg size and larval development time between lecithotrophic

Table 9. Mean ( \pm SD) chlorophyll a concentrations in Doubtful Sound between 14 December 1994 and 27 April 1995 for 6 depths between the surface and $100 \mathrm{~m}$

\begin{tabular}{|c|c|c|c|c|c|}
\hline \multirow[t]{2}{*}{ Date } & \multicolumn{5}{|c|}{ Chlorophyll a concentration ( $\mathrm{mg} \mathrm{m}^{3}$ ) } \\
\hline & Shelter Islands & Malaspina Reach & Crooked Arm & Fergusson Island & Hall Arm \\
\hline $14 \mathrm{Dec}$ & $0.776(0.306)$ & $1.054(1.188)$ & 1.790 & 1.740 & $1.027(0.834)$ \\
\hline $17 \mathrm{Jan}$ & $1.063(1.215)$ & $1.407(1.115)$ & $0.723(0.441)$ & $0.658(0.333)$ & $0.637(0.431)$ \\
\hline $9 \mathrm{Feb}$ & $0.522(0.286)$ & $0.934(0.433)$ & $0.123(0.060)$ & $0.145(0.078)$ & $0.295(0.128)$ \\
\hline 23 Feb & $0.520(0.963)$ & $0.459(0.726)$ & $0.337(0.436)$ & $0.584(0.662)$ & $0.988(0.978\}$ \\
\hline 7 Mar & $1.940(2.744)$ & $0.134(0.151)$ & $0.576(0.517)$ & $0.567(0.488)$ & $1.196(1.181)$ \\
\hline $5 \mathrm{Apr}$ & - & $0.404(0.202)$ & $0.265(0.174)$ & $0.338(0.284)$ & $0.607(0.607)$ \\
\hline $27 \mathrm{Apr}$ & - & $0.477(0.201)$ & $0.244(0.151)$ & $0.309(0.236)$ & $0.422(0.382\}$ \\
\hline
\end{tabular}


Table 10. Rates of larval mortality for marine invertebrate species and for echinoids using 4 methods of estimation. Results are presented for the current study and the average of previous studies

\begin{tabular}{|c|c|c|c|c|}
\hline & & \multicolumn{2}{|c|}{ Instantaneous mortality rate $\left(\mathrm{d}^{-1}\right)$} & \multirow[t]{2}{*}{ Source } \\
\hline & & All invertebrates & Echinoids & \\
\hline \multirow{3}{*}{ Current study } & Cohort analysis & & 0.164 & \\
\hline & KNM & & 0.173 & \\
\hline & Production-recruitment & & 0.092 & \\
\hline \multirow[t]{3}{*}{ Previous studies } & Cohort analysis & 0.247 & 0.162 & Rumrill (1990) \\
\hline & Production-recruitment & 0.147 & & Rumrill (1990) \\
\hline & Planktotrophic vs lecithotrophic & 0.154 & & Rumrill (1990) \\
\hline
\end{tabular}

larvae and planktotrophic larvae (Strathmann 1985, Emlet et al. 1987). Given several assumptions, including the assumption that the number of larvae surviving through to metamorphosis is equal in both larval types, then mortality can be calculated using the equation

$$
M=\left[\ln \left(0.75 E_{\mathrm{L}}\right)-\ln \left(0.75 E_{\mathrm{P}}\right)\right]\left(t_{\mathrm{p}}-t_{\mathrm{L}}\right)^{-1}
$$

where $E_{\mathrm{L}}$ and $t_{\mathrm{L}}$ are ova volume and development time of lecithotrophic larvae and $E_{\mathrm{p}}$ and $t_{\mathrm{p}}$ are ova volume and development time for planktotrophic larvae. Using 14 temperate Pacific asteroids as an example, Rumrill (1990) estimated the mortality ratio to be $M=0.154 \mathrm{~d}^{-1}$.

Mortality in Evechinus chloroticus larvae are within the range of these estimates, and are almost identical to estimates of larval mortality made for Strongylocentrotus spp. using the cohort analysis which average $M=0.162 \mathrm{~d}^{-1}$ (Table 10). It is interesting to note that both sea urchin genera are temperate and have similar larval life spans (25 to $40 \mathrm{~d}$ in $S$. droebachiensis [Hart \& Scheibling 1988] and 29 to 86 d in S. purpuratus [Strathmann 1987]). The comparisons suggest that for the pluteus stages of temperate echinoid larvae with a similar development time, mortality is in the order of $0.16 \mathrm{~d}^{-1}$.

In addition to calculating larval mortality, the KNM model estimated a number of key population parameters for Evechinus chloroticus larvae, including stage-specific survival and the time spent in each stage. If larval mortality is constant, then the stage-specific survival rate will be a function of the time spent in that stage. The KNM model estimated E. chloroticus larvae spend $44.9 \%$ of their development in the late 4 -armed stage, and as a consequence only $11.5 \%$ of late 4-armed pluteus $E$. chloroticus larvae survive through this stage. This prediction of an accumulation of larvae at this stage is consistent with observed temporal changes in the frequency distribution of developmental stages (Fig. 4), which showed that $98.0 \%$ of all larvae were in the late 4 -armed stage $18 \mathrm{~d}$ after spawning.

The accumulation of larvae in the 4 -armed stage may be a critical life history stage for Evechinus chloroticus, and a number of observations suggest that it is the result of food-limited development of these larvae. Firstly, a comparison of the development rates of E. chloroticus larvae in Doubtful Sound with laboratory cultures indicates that development was slower in Doubtful Sound (Table 11). While the developmental times to the 4-armed pluteus stage were similar in Doubtful Sound and in the laboratory (between 4 and 7 d), rates diverge with continued development. Both this study and Dix (1969) recorded a minimum development time in culture to the 6-armed pluteus stage of between 8.5 and $15 \mathrm{~d}$. In contrast, after $18 \mathrm{~d}$ development in Doubtful Sound, the majority of the population were late 4 -armed pluteus (98.0\%). Further comparisons of the development rates after $18 \mathrm{~d}$ are difficult due to the 2 wk interval in plankton samples and the large range of developmental stages found on 27 February. The samples do indicate, however, that by $31 \mathrm{~d}$ after fertilization $8.3 \%$ of the larval population was competent and that almost all the larvae completed development after $18 \mathrm{~d}$. In reality, the actual time that larvae completed development was probably closer to $31 \mathrm{~d}$, with $98.0 \%$ of larvae at the late 4 -armed stage at 18 d (laboratory cultures took a minimum of $11 \mathrm{~d}$ to complete development from the 4-armed stage; Table 11). The minimum time to competency in the laboratory is $17 \mathrm{~d}$. If the laboratory developmental rates represent maxima, then the time to complete development of between 18 and $31 \mathrm{~d}$ observed in Doubtful Sound is potentially 1.05- to 1.82-fold slower than the maximum rate. Secondly, the morphometrics of $E$. chloroticus larvae collected from Doubtful Sound (which have significantly longer postoral arms compared with laboratory-reared larvae) suggests that these larvae were morphologically adapted to lower phytoplankton concentrations (McEdward 1984, 1986, Boidron-Métairon 1988, Hart \& Scheibling 1988). Thirdly, E. chloroticus larvae reared in the laboratory at very low phytoplankton concentrations are able to develop through to the 4 -armed stage, but will remain in that stage until they die or are exposed to higher food concentrations (Lamare pers, obs.). A similar phenomenon may be occurring in Doubtful Sound with larvae reaching the late 4 -armed stage, but not contin- 
Table 11. Evechinus chloroticus. Time to development (days after fertilization) for larvae reared in the laboratory at $15^{\circ} \mathrm{C}$ (present study), $19^{\circ} \mathrm{C}$ (Dix 1969) and $20^{\circ} \mathrm{C}$ (Walker 1984) and estimated from larval cohorts tracked in Doubtful Sound

\begin{tabular}{|lcccccc|}
\hline & 4-armed & 6-armed & 8-armed & $\begin{array}{c}\text { Competent } \\
\text { larvae }\end{array}$ & $\begin{array}{c}\text { Newly } \\
\text { metamorphosed }\end{array}$ & $\begin{array}{c}\text { Water } \\
\text { temperature }\left({ }^{\circ} \mathrm{C}\right)\end{array}$ \\
\hline Present study & 5 & 8.5 & 14 & 22.5 & 15.4 \\
Dix (1969) & 4 to 6 & 10 to 15 & 13 to 17 & 17 to 22 & 28 to 36 & 19 \\
Walker(1984) & & & 18 & 23 & 31 to 43 & 20 \\
Doubtful Sound & 7 & & & Between 18 and 31 & & 12.5 to 17.2( $x=15.03)$ \\
\hline
\end{tabular}

uing to develop due to low food concentrations. Lastly, concentrations of chlorophyll a in Doubtful Sound are typically low (ranging between 0.123 and $1.790 \mathrm{mg} \mathrm{m}^{-3}$ ), suggesting low food concentrations in Doubtful Sound.

Given these observations, it is possible that the low food concentrations in Doubtful Sound mean that Evechinus chloroticus larvae are able to develop through to the 4-armed pluteus stage, but continued development is retarded. A consequence of this accumulation of larvae in the late 4-armed stage is a low survival rate past this stage. For other echinoid larvae, higher concentrations of food result in enhanced development rates (Pechenik 1987, Strathmann 1987. Boidron-Métairon 1995), and temporal increases in food concentrations in Doubtful Sound could result in enhanced development rates and subsequent settlement of E. chloroticus larvae. The effects of increased larval development rate on larval mortality and settlement can be quantified using Eq. (1). The development of E. chloroticus larvae in Doubtful Sound was estimated to be 1.05- to 1.82-fold slower than the maximum, and more favourable planktonic conditions in the fiord (greater food concentrations) would likely result in increased larval development rates. Given the current estimate of instantaneous mortality rate, $M=0.164 \mathrm{~d}^{-1}$, a 1.05 - to 1.82 -fold decrease in developmental time would result in a 9.2-fold increase in the number of larvae surviving to settlement. Settlement rates of $E$. chloroticus larvae on artificial settlement samplers at Espinosa Point, Doubtful Sound, varied interannually from a total of 9 to $79.0 \mathrm{yr}^{-1}$ (Lamare 1997). This represents an 8.7 -fold difference in settlement rates, which is in the range that could be explained by increases in development rates.

While temporal differences in gamete production, larval transport and mortality will also influence settlement rate, these results suggest that change in larval development rate is one factor that can potentially result in the observed variation in settlement and recruitment rates. Assessing the relative importance of each of the pre-settlement processes will require further examination of the larval biology of this species over a number of years.
Acknowledgements. Thanks to Paul Meredith, Clive Heseltine, Ewan Dickson (Fiordland Lobster Company), and Nicole Goebel for technical assistance, and to John Jillett for help with the analysis of plankton samples. This paper benefited from comments from Rachel Berquist, Richard Emlet, Brian Manly, Philip Mladenov, Richard Strathmann and Steve Wing. Research was funded by an Otago Research Grant provided by the University of Otago (NZ), and was generously supported by the Fiordland Lobster Company (NZ) and the Fiordland Travel Company (NZ).

\section{LITERATURE CITED}

Birkeland C (1982) Terrestrial runoff as a cause of outbreaks of Acanthaster planci (Echinodermata: Asteroidea). Mar Biol 69:175-185

Boidron-Métairon IF (1988) Morphological plasticity in laboratory-reared echinoplutei of Dendraster excentricus (Eschscholtz) and Lytechinus variegatus (Lamarck) in response to food conditions. J Exp Mar Biol Ecol 119:31-41

Boidron-Métairon IF (1995) Larval nutrition. In: McEdward L (ed) Ecology of marine invertebrate larvae. CRC Press, New York, p 223-248

Dix TG (1969) Larval life span of the echinoid Evechinus chloroticus (Val.). NZ J Mar Freshw Res 3:13-16

Emlet RB, McEdwards LR, Strathmann RR (1987) Echinoderm larval ecology viewed from the egg. In: Jangoux $M$, Lawrence JM (eds) Echinoderm studies, Vol 2. AA. Balkema, Rotterdam, p 55-136

Fenaux L, Cellario C, Rassoulzadegan F (1988) Sensitivity of different morphological stages of the larva of Paracentrotus lividus (Lamarck) to quantity and quality of food. In: Burke RD, Mladenov PV, Lambert P, Parsley RL (eds) 6th Int Echinoderm Conf, Victoria. AA Balkema, Rotterdam, p 259-266

Fenaux L, Greef YD, Cellario C (1992) Effets du retard dans la première alimentation sur le développement de la larve planctotrophe de l'oursin Paracentrotus lividus. Int Rev Ges Hydrobiol 77:651-663

Fenaux L, Strathmann MF, Strathmann RR (1994) Five tests of food-limited growth of larvae in coastal waters by comparisons of rates of development and form of echinoplutei. Limnol Oceanogr 39:84-98

Harris LG (1995) The effects of depth, water flow and diet on settlement, recruitment and growth of the green sea urchin Strongylocentrotus droebachiensis. In: Grassle JP, Kelsey A, Oates E, Snelgrov PV (eds) 23rd Benthic Ecology Meeting, 17-19 March, New Brunswick, NJ

Hart MW, Scheibling RE (1988) Comparing shapes of echinoplutei using principal components analysis, with an application to larvae of Strongylocentrotus droebachiensis. In: Burke RD, Mladenov PV, Lambert P, Parsley RL (eds) 6th Int Echinoderm Conf, Victoria. AA Balkema, Rotterdam, p $277-284$ 
Hernroth L (1987) Sampling and filtration efficiency of two commonly used plankton nets. A comparative study of the Nansen net and UNESCO WP2 net. J Plankton Res 9: $719-728$

Kiritani K, Nakasuji F (1967) Estimation of stage specific survival rate in the insect population with overlapping stages. Res Popul Ecol 9:143-152

Lamare MD (1997) Population biology, pre-settlement processes and recruitment in the New Zealand sea urchin, Evechinus chloroticus Valenciennes (Echinoided: Echinometridae). PhD thesis, University of Otago, Dunedin

Lamare MD (1998) Origin and transport of larvae of the sea urchin Evechinus chloroticus (Echinodermata: Echinoidea) in a New Zealand fiord. Mar Ecol Prog Ser 174: $107-121$

Lamare MD, Stewart BG (1998) Mass spawning by the sea urchin Evechinus chloroticus (Echinodermata: Echinoidea) in a New Zealand fiord. Mar Biol 132:135-140

Manly BFJ (1976) Extensions to Kiritani and Nakasuji's method for analysing insect stage-frequency data. Res Popul Ecol 17:191-199

McEdward LR (1984) Morphometric and metabolic analysis of the growth and form of an echinopluteus. J Exp Mar Biol Ecol 82:259-287

McEdward LR (1985) Effects of temperature on the body form, growth, electron transport system activity, and development rate of echinopluteus. J Exp Mar Biol Ecol 93:169-181

McEdward LR (1986) Comparative morphometrics of echinoderm larvae. 2. Larval size, shape, growth, and the scaling of feeding and metabolism in echinoplutei. J Exp Mar Biol Ecol 96:267-286

Morgan SG (1995) Life and death in the plankton: larval mortality and adaptation. In: McEdward L (ed) Ecology of marine invertebrate larvae. CRC Press, New York, p 279-322

Olson RR, Olson MH (1989) Food limitation of planktotrophic marine invertebrate larvae: does it control recruitment success? Annu Rev Ecol Syst 20:225-247

Paulay G, Boring I., Strathmann RR (1985) Food limited growth and development of larvae: experiments with natural sea water. J Exp Mar Biol Ecol 93:1-10

Pechenik JA (1987) Environmental influences on larval survival and development. In: Giese AC, Pearse JS, Pearse VB (eds) Reproduction in marine invertebrates, Vol 9, General aspects: seeking unity in diversity. Blackwell Scientific Publications, Palo Alto, CA, p 551-608

Editorial responsibility: Otto Kinne (Editor)

Oldendorf/Luhe, Germany
Pennington JT, Rumrill SS, Chia FS (1986) Stage-specific predation upon embryos and larvae of the Pacific sand dollar, Dendraster excentricus, by 11 species of common zooplanktonic predators. Bull Mar Sci 39:234-240

Pickard GL, Emery W (1982) Descriptive physical oceanography: an introduction. Pergamon Press, Oxford

Rasband W (1996) NiH image analyser 1.61. National Institute of Health, Washington, DC

Rowley RJ (1990) Newly settled sea urchins in a kelp bed and urchin barren ground: a comparison of growth and mortality. Mar Ecol Prog Ser 62:229-240

Rumrill SS (1987) Differential predation upon embryos and larvae of temperate Pacific echinoderms. PhD thesis, University of Alberta, Edmonton

Rumrill SS (1990) Natural mortality of marine invertebrate larvae. Ophelia 32:163-198

Rumrill SS, Chia FS (1985) Differential mortality during the embryonic and larval lives of northeast Pacific echinoids. In: Keegan BF, $\mathrm{O}^{\prime}$ Connor BDS (eds) 5th Int Echinoderm Conf, Galway. AA Balkema, Rotterdam, p 333-338

Rumrill SS, Pennington JT, Chia FS (1985) Differential susceptibility of marine invertebrate larvae: laboratory predation of sand dollar, Dendraster excentricus (Eschscholtz), embryos and larvae by zoeae of the red crab, Cancer productus Randall. J Exp Mar Biol Ecol 90: $193-208$

Strathmann RR (1985) Feeding and nonfeeding larval development and life-history evolution in marine invertebrates. Annu Rev Ecol Syst 16:339-361

Strathmann RR (1987) Larval feeding. In: Giese AC, Pearse JS, Pearse VB (eds) Reproduction in manine invertebrates, Vol 9, General aspects: seeking unity in diversity. Blackwell Scientific Publications, Palo Alto, CA, p 465-550

Strickland JDH, Parsons TR (1972) A practical handbook of seawater analysis. Bull Fish Res Board Can 167

UNESCO (1968) Zooplankton sampling. Monographs on oceanographic methodology. UNESCO, Paris

Walker MM (1984) Larval life span, larval settlement, and early growth of Evechinus chloroticus (Valenciennes). NZ J Mar Freshw Res 18:393-397

Young CM, Chia, FS (1987) Abundance and distribution of pelagic larvae as influenced by predation, behavior, and hydrographic factors. In: Giese AC, Pearse JS, Pearse VB (eds) Reproduction of marine invertebrates, Vol 9, General aspects: seeking unity in diversity. Blackwell Scientific Publications, Palo Alto, CA, p 385-463

Submitted: August 18, 1998; Accepted: December 7, 1998 Proofs received from author(s): April 13, 1999 